\title{
Multilevel Analysis on the Risk Factors of Post Partum Hemorrhage in Bondowoso, Central Java
}

\author{
Miftahus Saadah'), Supriyadi Hari Respati²), Okid Parama Aristin3) \\ 1)Academy of Midwifery Dharma Praja, Bondowoso, East Java \\ 2)Department of Obstetrics and Gynecology, Dr. Moewardi Hospital, Surakarta \\ 3)Faculty of Mathematics and Natural Sciences, Universitas Sebelas Maret
}

\begin{abstract}
Background: The primary causes of maternal mortality in Indonesia are hemorrhage (32\%), preeclampsia/ eclampsia (25\%), infection (5\%), prolonged labor (5\%), abortus (1\%), and other causal factors not related to pregnancy and birth delivery (32\%). This study aimed to investigate risk factors of post partum hemorrhage in Bondowoso, East Java.

Subjects and Method: This was an analytic observational study with case control design. This study was conducted in Bondowoso, East Java, from May, 15 to June, 15, 2016. A total of 90 study subjects was selected by fixed disease sampling, consisting of 30 women with post-partum bleeding and 60 control women without post-partum bleeding. The dependent variable was post-partum hemorrhage. The independent variables were age, parity, hemoglobin, obstetric history, antenatal care (ANC), and type of birth attendant. The data were collected by questionnaire and medical record. The data were analyzed by mix-effect model.

Results: Anemia $(\mathrm{Hb}<11 \mathrm{~g} \%)(\mathrm{b}=2.22 ; 95 \% \mathrm{CI}=1.05$ to $3.39 ; \mathrm{p}=0.001)$ and obstetric history of bleeding $(\mathrm{b}=1.31 ; 95 \% \mathrm{CI}=0.15$ to $2.47 ; \mathrm{p}=0.027)$ increased the risk logodd of postpartum hemorrhage, and it was statistically significant. ANC $\geq 4$ times $(b=-1.46 ; 95 \% C I=-2.95$ to $0.02 ; p=$ 0.052) decreased the risk logodd of postpartum hemorrhage, and it was marginally significant. Age $<20$ year or $\geq 35$ year $(\mathrm{b}=0.12 ; 95 \% \mathrm{CI}=-1.01$ to $1.26 ; \mathrm{p}=0.827)$ and parity $=1$ or $\geq 4(\mathrm{~b}=0.18$; $95 \% \mathrm{CI}=-0.95$ to $1.32 ; \mathrm{p}=0.754$ ) increased the risk logodd of postpartum hemorrhage, but it was not statistically significant. Multilevel analysis was not needed in this model because ICC $<1 \%$.

Conclusion: Anemia and history of postpartum bleeding are important risk factors of postpartum hemorrhage. Use of ANC $\geq 4$ times decreases the risk of postpartum bleeding.
\end{abstract}

Keywords: Postpartum bleeding, risk factor.

\section{Correspondence:}

Miftahus Saadah. Academy of Midwifery Dharma Praja, Bondowoso, East Java. Email: meef_tah@yahoo.com.

\section{BACKGROUND}

$\overline{\text { One of the biggest causes of maternal morta- }}$ lity in developing countries is hemorrhage after giving birth or commonly known as postpartum hemorrhage. Postpartum hemorrhage cannot be predicted beforehand. The majority of postpartum hemorrhage occur due to uterine atony (Maternal Child and Health Integrated Program 2011).

The cause of maternal mortality in Indonesia is still dominated by hemorrhage (32\%), pre-eclampsia/ eclampsia (25\%), infection ( $5 \%)$, prolonged labor (5\%), abortus
(1\%) and other causal factors not related to pregnancy and birth delivery (32\%). Obstetric complications on mother should be handled by doing three things. The first is being aware of any obstetric complications that cannot be predicted beforehand because each pregnant woman has that risk. Second, every mother should have access to adequate health services needed when complications occur. Third, the quality of service must be the top priority of health workers, especially in the first 24 hours of labor because maternal mortality 
mostly occur in this period. These three things are often neglected because of the $3 \mathrm{~T}$ namely too late in making decisions, too late in reaching hospital and having ineffective referrals and references, also too late in getting adequate help at the referral hospital (Ministry of Health of the Republic of Indonesia 2013).

Based on data from the East Java Provincial Health Office in 2012, the City of Bondowoso is still included in the districts/ cities in East Java that have maternal mortality rate above the provincial rate by 109.50 mothers/ 100,00o live births. The maternal mortality rate in Bondowoso Regency increased in 2014, from 17 people to 19 people in 2015. Patients with postpartum hemorrhage in Bondowoso District were recorded in 2011 as many as 264 people, then it decreased in 2012 to 223 people, in the year 2013 it decreased to 211 people, while in 2014 maternal hemorrhage increased again to 235 people. These incidents of hemmoraghe during the 4 year period occured in health facilities at the Village Maternity Cottage level, Community Health Centers, Private Practice Midwives and in Private Hospitals and Public Hospitals (Bondowoso Health Office, 2014).

Uterine atony is the major and the most frequent cause in the case of postpartum hemorrhage, the uterus fails to contract and does not shrink after the baby is born. The implementation of active management in the third stage is very instrumental in the prevention and handling of hemorrhage. The active management of the third stage consists of the provision of uterotonic, controlled cord traction (CCT) and uterine fundus massage. The role of health workers, especially midwives, is very influential in the active management of the third stage, the ability of midwives with the skills they have in assisting the labor has a large effect on patients who give birth (MCH IP, 2011).

The more risk factors on mother, the incidence of postpartum hemorrhage will increase, specifically related to age, parity and obstetric history. Parity factors and $\mathrm{Hb}$ levels in maternity are the most potential factors in the incidence of postpartum hemorrhage. This happens because women with high parity have decreased reproductive function. Whereas women with $\mathrm{Hb}$ levels of less than $11 \mathrm{~g} \%$ will experience weak uterine muscle contractions during labor (Dina, Seweng, \& Nyorong 2013). Al Zirqi (2008) also stated that parity and smoking are the factors that have an effect on the incidence of postpartum hemorrhage. The midwife's education level and midwife's working experience / duration as a delivery helper have an effect on the incidence of postpartum haemorrhage, if the midwife has longer practical experience, the midwife will be responsive and alert in overcoming some obstetric complications so that the occurrence of complications can be avoided or not even occur (Pardosi, 2005).

In 2012, the East Java Health Office formed a forum called Decreasing Maternal and Infant Mortality. The forum consisted of 3 task forces, namely the referral task force, the basic health task force and the community empowerment task force. The task of each task force is to examine the causes of maternal and infant mortality. Another program that is carried out is the Joint Movement to Secure Pregnancy Program, this program was carried out starting in 2013 by providing assistance for high risk pregnant women conducted for 10 months from pregnancy to postpartum involving cadres in Family Welfare Guidance Program and midwifery academy students in East Java. This program is expected to be able to detect early complica- 
tions in pregnant women so that early prevention and treatment can be done immediately by health workers to avoid problems in pregnancy, childbirth and puerperium, one of which is postpartum hemorrhage.

\section{SUBJECTS AND METHOD}

This was an epidemiological study that is analytic observation with a Case Control Study design. Case Control Study is an epidemiological study that studies the relationship between exposure (study factors) and disease, by comparing case group and control group based on their exposure status (Murti, 1997). The sampling tech- nique used was purposive sampling technique. The sample was selected using the Fixed Disease Sampling, with a comparison (1: 2) with a control case of 30 case subjects and 60 control subjects. Independent variables: level 1 were maternal $\mathrm{Hb}$ levels, maternal obstetric history, maternal parity, maternal age, maternal ANC and level 2 were birth attendants (midwives). The dependent variable were postpartum hemorrhage. Data processing was done bivariately to find out the relationship between variables using chi-square and analyzed by multilevel logistic regression.

Table 1. Logistic regression results with a multilevel analysis approach of risk factors for postpartum haemorrhage

\begin{tabular}{|c|c|c|c|c|}
\hline \multirow{2}{*}{ Independent Variable } & \multirow{2}{*}{$\mathbf{b}$} & \multicolumn{2}{|c|}{$95 \%$ CI } & \multirow[b]{2}{*}{$\mathbf{p}$} \\
\hline & & Lower limit & Upper limit & \\
\hline \multicolumn{5}{|l|}{ Fixed Effect } \\
\hline Anemia $(<11 \mathrm{~g} \%)$ & 2.22 & 1.05 & 3.39 & 0.001 \\
\hline $\begin{array}{l}\text { History of obstetrical } \\
\text { hemorrhage }\end{array}$ & 1.31 & 0.15 & 2.47 & 0.027 \\
\hline $\mathrm{ANC} \geq 4$ times & -1.46 & -2.95 & 0.02 & 0.052 \\
\hline Age $<20$ or $\geq 35$ year & 0.12 & -1.01 & 1.26 & 0.827 \\
\hline Parity 1 or $\geq 4$ & 0.18 & -0.95 & 1.32 & 0.754 \\
\hline Constanta & -2.50 & -3.78 & -1.23 & 0.001 \\
\hline \multicolumn{5}{|l|}{ Random Effect } \\
\hline Var midwives (constanta) & $<0.001$ & & & \\
\hline $\begin{array}{l}\text { Log likelihood } \\
\mathrm{p}=0.006 \\
\mathrm{ICC}<1 \%\end{array}$ & $=-45.71$ & & & \\
\hline
\end{tabular}

\section{RESULT}

The characteristics of this study subjects were maternal age that were divided into 2 , namely age $<20$ or $\geq 35$ years $(33 \%)$ in the case group and (25\%) in the control group, the second age $20-35$ years (67\%) in the case group and (75 \%) in the control group. Maternal parity was divided into 2, they are parity 1 and $>4$ (43\%) in the case group and (45\%) in the control group and 2-4 parity (57\%) in the case group and (55\%) in the control group. Maternal $\mathrm{Hb}$ levels were divided into two namely anemia <11 g\% there are $(80 \%)$ case group and (38\%) in the control group while the second was not anemia with $\mathrm{Hb}$ level $\geq 11 \mathrm{~g} \%$ by (20\%) in the case group and (62\%) in the control group. Mothers who had a history of obstetric hemorrhage (57\%) in the case group and (33\%) in the control group, while mothers with no history of obstetric hemorrhage (43\%) in the case group and (67\%) in the control group.

Mothers who underwent ANC <4 times were $(13 \%)$ in the case group and (18\%) in the control group while mothers who underwent $\mathrm{ANC} \geq 4$ times were (87\%) in case group and (82\%) in control group. Multivariate effects explained the influence of more than one independent variables. 
They were maternal age, maternal $\mathrm{Hb}$ levels, ANC, obstetric history, maternal parity and maternal birth attendants (midwives). The method used was logistic regression with multilevel analysis using the STATA 13 program.

\section{DISCUSSION}

The results showed that mothers aged $<20$ or $\geq 35$ years had a risk of 0.18 times lower than mothers aged 20-35 years $(\mathrm{b}=0.18$; 95\% CI $=-1.01$ to $1.26 ; \mathrm{p}=0.082$ ). Based on the results of this study, there was no influence of the age of mothers on postpartum hemorrhage. The number of mothers aged $<20$ years or $\geq 35$ years in this study were 25 people, 10 people in the case group and 15 people in the control group.

Mothers aged <20 years had reproductive functions that have not developed properly so they were not ready for pregnancy and childbirth. Whereas, at the age of $\geq 35$ years there was a progressive setback of the endometrium which affects the strength of contractions during labor and after delivery (Sulistiyani, 2010). One of the predisposing factors for postpartum hemorrhage due to uterine atony is that the age is too old or too young (Mochtar, 2007).

The number of subjects of this study were mothers aged $<20$ or 35 years who experienced postpartum hemorrhage. There were $33 \%$ in the case group and in the control group there were only $25 \%$ so that it would likely affect the results during the analysis.

According to National Family Planning Coordinating Agency (2006), if you want to have a healthy reproductive system you should avoid "4 too." Two of them are related to maternal age. First, too young means pregnant at the age of less than 20 years. As for the risks there may be abortus, pre-eclampsia, eclampsia, the emergence of difficulties in labor because the repro- ductive system is not developed well, prematurity, and low birth weight. The next "too" is too old which means getting pregnant at $\geq 35$ years. Risks that may occur are miscarriage, preeclampsia, eclampsia, prolonged labor, hemorrhage, low birth weight and congenital defects. Some ways that have been done by health workers and extension officers are to avoid early marriage which results in pregnancy and childbirth $<20$ years and provide IEC about family planning and reproductive health to avoid pregnancy at the age of $\geq 35$ years.

This result is in accordance with Suryani's study (2008) which stated that age was not significant because $\mathrm{p}<0.05$; $\mathrm{b}$ $=0.07$ meant that mothers at age $<20$ or $\geq 35$ years had a lower risk than mothers aged 20-35 years to experience postpartum homerrhage.

Mothers with parity 1 and $>4$ had a risk of having postpartum hemorrhage 0.18 times lower than mothers with parity 2-4, $(b=0.18 ; 95 \% \mathrm{CI}=-0.95$ to $1.32 ; \mathrm{p}=0.754)$. This shows that there was no influence of parity 1 on parity $>4$. Most mothers who were the subjects of the study are mothers with 2-4 parity.

The uterine condition of the mother in the first time of giving birth and after giving birth for several times affect the condition of the uterus. Parity 1 causes mothers to be unprepared for childbirth so that pregnant women are unable to handle complications that occur during pregnancy, childbirth and puerperium. Whereas parity $>4$ is caused because the mother gives birth more often, then the uterus tends to work inefficiently in all times of labor, causing compression failure at the place of placenta implementation. As a result, postpartum hemorrhage occurs. In addition, high parity can trigger a partial loss of placental tissue in the uterus and can cause postpartum hemorrhage (Cunningham, 2005). The birth attendants' 
ability in this study plays an important role because it can prevent and anticipate postpartum hemorrhage with parity 1 or $\geq 4$.

This study is in accordance with the research of Lubis (2011) which stated that parity did not significantly affect postpartum hemorrhage. Statistically, parity did not significantly affect postpartum hemorrhage $(\mathrm{p}=0.49)$. Postpartum hemorrhage may be caused by several things, one of which is regularly undergoing antenatal care so that the mother's health condition is monitored. In addition, steps in safe delivery assistance from postpartum hemorrhage in mothers with second high parity can be prepared (Eriza et al., 2012).

There was an influence of maternal $\mathrm{Hb}$ levels on the occurrence of postpartum bleeding. Mothers with $\mathrm{Hb}$ levels < $11 \mathrm{~g} \%$ had a 2.22 times greater risk of postpartum hemorrhage than mothers with $\mathrm{Hb}$ levels b11 g\% (b = 2.22; 95\% CI = 1.05 to 3.39; $\mathrm{p}=$ 0.001). This showed that there was a significant influence of $\mathrm{Hb}$ levels on the incidence of postpartum hemorrhage. The results of this study are in line with Syafneli's (2009) study, that there was a significant relationship between $\mathrm{Hb}$ levels in mothers with the incidence of postpartum hemorrhage.

Hemoglobin is needed by the human body for various cell metabolism in carrying oxygen throughout the body. The condition that worried is the condition after giving birth, namely the uterine organ requires strong contractions at the labor time and stopping bleeding due to the release of the placenta from its attachment on the deep surface of the uterus (endometrium) during pregnancy and after childbirth to reduce (involution) the uterus. Hb levels less than $11 \mathrm{~g} \%$ will make the uterine muscle contraction weaker when labor takes place (uterine atony) and also cause the danger of postpartum hemorrhage so that it becomes a potential cause of maternal and child morbidity and mortality (Prawirohardjo, 2007). During pregnancy, there is an increase in plasma volume by $50 \%$ while red blood cells only increase by $18 \%$ resulting in a decrease in the $6 \%$ hematocrit which is equivalent to $2 \mathrm{~g} \% \mathrm{Hb}$. This change occurs in the second and third trimesters of a pregnancy (WHO, 2009).

A study by Rosmeri (2000), produced statistical tests with results of the odds ratio 4.27. This meant that mothers with $\mathrm{Hb}$ levels $<11 \mathrm{~g} \%$ have a significant influence on the incidence of postpartum hemorrhage. Extensive prevention of anemia had been carried out for all pregnant women in the form of 90 tablets provision of iron suplement during pregnancy to prevent postpartum bleeding that can result in maternal and fetal death (Indonesian Ministry of Health, 2002).

There was a maternal obstetric history influence on the incidence of postpartum hemorrhage. Mothers with obstetric history during pregnancy, childbirth and postpartum had a greater risk than mothers without obstetric history $(b=1.31 ; 95 \% \mathrm{CI}=$ 0.15 to $2.47 ; \mathrm{p}=0.027)$. This showed that there was a significant influence of the maternal obstetric history on postpartum hemorrhage. Mothers who have an obstetric history during pregnancy, childbirth and the puerperium have a risk of having postpartum hemorrhage by 1.31 times. This research is in line with Dina's (2013) study which stated that there was a relationship between obstetric history and the incidence of postpartum hemorrhage, namely Odds Ratio 3.1, which meant mothers who had an obstetric history have 3.1 times greater risk of postpartum hemorrhage.

Obstetric history is closely related to pregnancy, labor and puerperium in the following period. If the labor history is poor, the officer must be aware of complica- 
tions in pregnancy, labor and puerperium. Vigilance must be increased if there has been an obstetric history in the previous period by frequently checking her pregnancy. This is also related to labor history without intervention, because the mother who gave birth with intervention tends to have labor with intervention at the next labor. For example, mother who gives birth to the first child by caesarean section because of the pelvis is narrow, will experience the same thing for the next labor. In addition, mothers who give birth with intervention tend to need help in daily activities, especially in postpartum care for the baby or herself. Conversely, women with a history of spontaneous labor usually find no difficulties during their postpartum care, because the labor is physiological and not manipulated (Syriac, 2008).

A study by Suryani (2008), obtained the same results. The risk for postpartum hemorrhage in mothers who have an obstetric history is 5,165 times greater than mothers who do not have an obstetric history. Mothers who underwent ANC visit $\geq 4$ times could reduce the incidence of postpartum hemorrhage compared to mothers who underwent ANC visit $<4$ times $(b=-$ $1.46 ; 95 \% \mathrm{CI}=-2.95$ to $0.01 ; \mathrm{p}=0.052)$.

ANC for monitoring and supervising maternal and child welfare of at least four times during pregnancy in the following times: first trimester pregnancy $\quad(<14$ weeks) one visit, second trimester pregnancy (14-28 weeks) one visit, and trimester pregnancy three (28-36 weeks to birth) two visits (Saifuddin 2008). Mothers who underwent $\mathrm{ANC} \geq 4$ times tend to know more about pregnancy, childbirth and puerperium and pay more attention to health, for example in choosing quality ANC services. Quality services are not only measured by the ability of technicians and facilities owned but by the attention and views of health workers on obstetric service problems in the community (Suryani, 2008).

The results of the study are in line with the study conducted by Aeni (2012), where incomplete antenatal examinations increased the risk of maternal mortality to 7.86 times. Mothers who underwent ANC $<4$ times are at a risk of 4.57 times greater complications during labor or the puerperium because of the women who are regularly undergoing ANC. In this study most of the mothers had undergone ANC $\geq 4$ times because the role of health workers was very good so that the society understood the importance of antenatal care.

The results showed that type of birth attendant (midwives) did not have a contextual effect on the occurrence of postpartum hemorrhage. This figure is smaller than the benchmark figure of Intra Class Correlation $8-10 \%$, so the contextual effect of midwives indicated by multilevel analysis does not need to be investigated.

Midwives as birth attendants have a great responsibility and workload in serving the community. Therefore, there are several things that must be really considered in carrying out their responsibilities. The midwife must at least complete her education at the third level of associate degree. In addition, birth attendants (midwives) must have at least 2-5 years of experience as an initial provision in carrying out their responsibilities before having an independent clinic. According to Renstra (2005), MPS (Making Pregnancy Suffer) 2001-2010 in improving maternal and newborn health has a strategy for the availability of postpartum health services by competent and skilled health workers. If work experience is improved, it will reduce the incidence of postpartum hemorrhage and other complications during labor and childbirth. In addition to birth attendants, 
there are several things that must also be considered so that pathological incidences in the labor process do not occur, such as family preparation in decision making, sterility of the place of delivery and availability of equipment in health care.

In addition to the existence of midwives as birth attendants, there are other factors that influence the incidence of complications after delivery. These factors are three late caused by individuals and families. The first is late in making decisions. The culture of "negotiation" in decision making becomes a factor that can hinder the referral process when there is an emergency. Delays also occur because the knowledge of mothers and families is lacking, perceptions of bleeding for mothers and families are different from the existing theories. The family thinks that the blood coming out is still within normal limits and the mother feels her body still feels strong enough even though the mother has had to change the fabric three times. The second is late in reaching the reference point due to geography and transportation factors. The third is late because of the availability of blood in the hospital so families must look elsewhere (Arulita, 2007).

The results of this study are not in line with a study by Febriana (2007), that birth attendants (midwives) as health workers influence the incidence of childbirth and childbirth complications, namely postpartum bleeding and death mother.

There was an influence on maternal $\mathrm{Hb}$ levels on the risk of postpartum haemorrhage $(p=0.001)$. There was no influence of the maternal age on the risk of the incidence of postpartum hemorrhage $(p=$ o.827). There was an influence of obstetric history on the incidence of postpartum hemorrhage $(p=0.027)$. There was no influence of parity on the risk of postpartum hemorrhage $(\mathrm{p}=0.754)$. There was an influence of ANC on the risk of postpartum hemorrhage $(p=0.052)$. There was no influence of birth attendants (midwives) on postpartum hemorrhage (ICC $=2.67 \%$ ).

\section{REFERENCE}

Agency For Healthcare Research and Quality (AHRQ) (2015). Management of postpartum haemorraghe, (51).

Al Hazmi S (2013). Faktor-Faktor yang Mempengaruhi Kejadian Perdarahan Postpartum (skripsi). Yogyakarta.

Al-Zirqi, Vangen S, Forsen L, Stray B, Pedersen (2008). Determine The Prevalence, Causes, Risk Factors and Acute Maternal Complication of Severe Obstetric Haemorrhage, Oslo.

Asuhan Persalinan Normal (APN) (2008). JNKP-KR, Jakarta

Badan Pusat Statistik, Badan Koordinasi Keluarga Berencana Nasional. Departemen Kesehatan dan Makro Internasional Survei Kesehatan Reproduksi Remaja. 2007. Jakarta.

Departemen Kesehatan Republik Indonesia (2008). Asuhan Persalinan Normal

Departemen Kesehatan Republik Indonesia (2008). Pembagian Anemia Pada Ibu Hamil.

Departemen Kesehatan RI (2013). Rencana Aksi Percepatan Penurunan Angka Kematian Ibu di Indonesia.

Dewi R (2015). Determinan Asuhan Kebidanan di Puskesmas Berkaitan dengan Kematian Maternal (tesis), Jawa Tengah.

Dina D, Seweng A, Nyorong M (2013). Faktor-Faktor Kejadian Postpartum RSUD Majene (tesis), Majene.

Dinas Kesehatan Kabupaten Bondowoso (2015). Data Perdarahan pasca persalinan Tahun 2011,2012,2013, 2014.

Dinas Kesehatan Provinsi Jawa Timur, (2014). Angka Kematian Ibu Tahun 2014. 
Djaja, Sarimawar, Suwandono (2006). The Determinasi of Maternal Morbidity in Indonesia. Regional Health Forum who South-East Asia Region, 4.

Eriza, N, Defrin, Lestari Y (2012). Hubungan Perdarahan Pasca Persalinan dengan Paritas di RSUP Dr. M. Djamil Periode 1 Januari-31 Desember 2012.

Fibriana A (2007). Faktor-faktor Risiko yang Mempengaruhi Kematian Maternal di Cilacap.

Siswanto E (2011). Faktor-Faktor Penolong Persalinan (Bidan) dengan Kejadian Perdarahan Pasca Persalinan (tesis), Semarang.

Fransisca SK (2010). Perdarahan Postpartum (jurnal), Universitas Wijaya Kusuma Surabaya.

Frass K (2014). Postpartum Hemorraghe is Related to The Hemoglobin Levels at Labor, Elsevier.

Hadi A (2008). Implementasi Manajemen Aktif Kala III Oleh Bidan Bersertifikat APN di Kodya Medan (tesis), USU Repository.

Kementrian Kesehatan RI (2012). Profil Kesehatan Indonesia, Jakarta

Manuaba I (1998). Ilmu Kebidanan Penyakit Kandungan dan Keluarga Berencana untuk Pendidikan Bidan. Jakarta: EGC.

Masyuni (2010). Analisis Faktor-Faktor yang Berhubungan dengan Perdarahan Postpartum Primer, Rokan Hulu.

Maternal and Child Health Integreted Program Prevention and Threatment of Postpartum Haemorraghe at The Community Level (MCHIP) (2011). 2nd edition, Baltimore.

Millennium Development Goals (2008). Angka Kematian Ibu, United Nations Indonesia.

Mochtar R (2008). Sinopsis Obstetri Fisiologi dan Patologi, EGC Jakarta
Murti B (2013). Desain dan Ukuran Sampel untuk Penelitian Kuantitatif dan Kualitatif di Bidang Kesehatan, Yogyakarta: Gajah Mada University Pres.

Pardosi M (2005). Analisis Faktor-Faktor yang Berhubungan dengan Perdarahan Pasca Persalinan dan Upaya Penurunannya, Medan.

Prawirohardjo (2005). Ilmu Bedah Kebidanan. Jakarta: Yayasan Bina Pustaka Sarwono Prawirohardjo.

Priority medicines for Europe and the world, The Woman's (2013). Post Partum Haemorraghe. BP6_16PPH.

Rahmi (2009). Karakteristik Penderita Perdarahan Postpartum yang Datang di RSUD Pirngadi, Medan.

Royston E, Amstrong S (1998). Pencegahan Kematian Ibu Hamil. Jakarta: Binarupa Aksara

Saifudin AB (2008). Buku Acuan Nasional Pelayanan Kesehatan Maternal dan Neonatal. Jakarta: Yayasan Bina Pustaka Sarwono Prawirohardjo.

Santoso W (2010). Hubungan kejadian anemia kehamilan dengan perdarahan postpartum (tesis), Ngawi.

Sheldon WR, Blum J, Vogel JP, Souza JP (2014). Postpartum haemorrhage management, risks and outcomes (tesis), New York.

Suprijati, Wahyuni S (2014). Hubungan keberhasilan penatalaksanaan atonia uteri dengan perdarahan pasca persalinan di BPM Wilayah Madiun Selatan, Jurnal Delima Harapan 3(2): 56-66

Suryani (2008). Hubungan Karakteristik Ibu Bersalin dan ANC dengan Perdarahan Pasca Persalinan di RSUD Pringadi (tesis), Medan

SDKI (2012). Estimasi Angka Kematian Maternal.

Syafneli, Masyuni S (2010). Analisis faktor-faktor yang berhubungan 
dengan perdarahan postpartum primer (tesis), Rokan Hulu.

Varney H (2008). Buku Ajar Asuhan Kebidanan Edisi I. Jakarta: EGC

Vera M (2014). Obstetrical Nursing Postpartum (Postpartum Complications).

WHO (2011). Anemia Prevention and Control. Geneva.
WHO (2009). Guidelines The Management of Postpartum Haemorrhage and Retained Placenta.

Yetti M (2010). Determinan Kejadian Komplikasi Persalinan di Indonesia (Analisis SDKI Tahun 2007), Depok.

Zaman S, Bushra (2007). Risk Factors for Primary Postpartum Haemorrage. Profesional Med J. 14 (3): 378-379. 